\title{
The Impact of FDI on Poverty Reduction in North Africa
}

\author{
Marwa Lazreg ${ }^{1} \&$ Ezzeddine Zouari. ${ }^{1}$ \\ ${ }^{1}$ Faculty of Economic Sciences and Management of Sousse, University of Sousse, Tunisia \\ Correspondence: Marwa Lazreg, Faculty of Economic Sciences and Management of Sousse, University of Sousse, \\ Tunisia. Tel: 0021699428 500. E-mail: marwa.lazreg87@gmail.com
}

Received: April 5, 2018; Accepted: April 22, 2018; Published: May 3, 2018

\begin{abstract}
The aim of this paper is to study the impact of FDI on poverty in the case of the North African country during the period from 1985 to 2005. The sample used in this paper consists of 6 countries of North Africa during the period from 1985 to 2005. So we can use the cointegration test. For the cointegration test, we have certified the existence of a cointegration relationship between the different series studied in our paper. Indeed, the result of the null hypothesis test of no cointegration was rejected at the 5\% threshold, which explains the presence of a cointegration relationship. Also, to test the effect of FDI on poverty in the countries of North Africa, we will perform a FMOLS estimate. Thus, for the short-term dynamics, we noticed that FDI have a positive and significant impact on a threshold of $1 \%$ on the GINI index for the case of the countries of North Africa and a significant negative a threshold of $1 \%$ for the other two indicators of poverty; LPOV1_91 \$ and LPOV3_1 \$. Then we found that is statistically significant and positive at a $1 \%$ level. The LIDE variable measuring foreign direct investment has a negative impact on the Gini index to a threshold of 5\%.For the Granger causality test; we notice that there is a unidirectional relationship between the consumption of energy and poverty Granger. Only the GINI index can cause Granger consumption of energy.
\end{abstract}

Keywords: IDF, poverty, North Africa, cointegration, FMOLS

\section{Introduction}

The indirect impact of FDI on poverty reduction through economic growth and FDI relationship was widely covered in the literature. The majority of these studies assume that what is good for growth is good for the poor (Sumner, 2005). The lack of a simple positive impact of FDI on poverty reduction motivated investigations on the possible direct impact of FDI on poverty reduction. The literature on the direct impact of FDI on poverty reduction is still insufficient.

Although the Millennium Development Goal (MDG) of reducing extreme poverty and hunger by 2015 has been met at the global level, some countries still experiencing high levels of poverty. While the struggle for the eradication of poverty continues, the MDGs was signed in 2015 within the United Nations sustainable development goals, strengthening the pressure on developed and developing governments to seek solutions to reducing poverty in national and international relations.

The conflicting findings about the relationship between FDI and poverty reduction policymakers have left a number of questions about the benefits that can be derived from liberal policies that encourage FDI flows.

Existing studies, which are based on different countries, poverty indicators and various econometric approaches, have failed to provide a conclusive answer to the link between FDI and poverty.

The impact of FDI on poverty reduction has been the subject of much controversy and so far, investigations are continuing in order to disentangle the possible benefits of FDI for poverty reduction.

The literature on the impact of FDI on poverty is divided between the search for a positive impact of FDI on poverty reduction, and a negative impact, or an insignificant impact of FDI on reducing poverty.

Some of the positive contributions of FDI on poverty reduction are achieved through spillover effects in job creation and increased investment capital (Meyer, 2004; Gorg and Greenaway, 2004). The literature that supports a negative or insignificant impact of FDI on poverty reduction is covered by the dependency theory, which explains the underdevelopment of developing countries and how the nature of development leads to poverty. 
The spillover effects can be divided into two categories, namely horizontal and vertical. The horizontal spillovers arising from non-contractual and non-market operations, where external parties, in this case the domestic companies, benefit from resources from foreign companies (Meyer, 2004).

These benefits are also called externalities (Meyer, 2004). According to Meyer (2004), spillover effects in this category occur mainly in intra-industry configuration.

Thus, this paper has been devoted to relevant empirical study to clarify the impact of FDI on poverty in the case of the North African country during the period from 1985 to 2005. The sample used in our paper consists of 6 countries of North Africa during the period from 1985 to 2005. We concluded that on the basis of the test statistics of Im-Pesaran-Shin (IPS) test, ADF-Fisher test and PP-Fisher test, we can conclude that only three variables LIDE, LPIB, LINF and are stationary in LUE level. But first difference, all variables are stationary according to these three tests. Thereafter, all the variables are integrated of order 1. Thus, we can use the cointegration test. For the co-integration test, we have certified the existence of a cointegration relationship between the different series studied in our paper. Indeed, the results of the null hypothesis test of no cointegration were rejected at the 5\% threshold, which explains the presence of a cointegration relationship.

The results of these tests can determine the use of an error correction model. Also, to test the effect of FDI on poverty in the countries of North Africa, we will perform a FMOLS estimate. Thus, for the short-term dynamics, we noticed that FDI have a positive and significant impact on a threshold of $1 \%$ on the GINI index for the case of the countries of North Africa and a significant negative a threshold of $1 \%$ for the other two indicators of poverty; LPOV1_91 LPOV3_1 \$ and \$. Then we found that is statistically significant and positive at a 1\% level. Noula LIDE variable measuring foreign direct investment has a negative impact on the Gini index to a threshold of 5\%. That is to say, if the level of FDI increased by 5 units, then the GINI index decreases by 0.007476 units. For the Granger causality test, we noticed that there is a unidirectional relationship between the consumption of energy and poverty Granger. Only the GINI index can cause Granger consumption of energy.

The rest of the paper is organized as follows: In Section 2, we present a literature review. The third section summarizes the econometric methodology. Data are presented in Section 4. Section 5 was dedicated to the interpretation of results. The conclusion is made in section 6 .

\section{Literature review}

Hung (1999) analyzes the relationship between FDI and poverty between 1992 and 2002 in a sample of 12 cities in Vietnam. He uses the incidence of poverty as a measure of poverty. Hung (1999) finds that a $1 \%$ increase in FDI has reduced the number of people living in poverty by $0.05 \%$. This direct impact of FDI on poverty reduction was rated higher than the indirect effects of GDP growth.

Similarly, Jalilian and Weiss (2002) study the relationship FDI-growth-poverty the CountryASEAN (ASEAN). They took a sample of 26 countries including 18 ASEAN countries are developing and 8 developed countries, the authors use the method of unbalanced panel data (unbalanced panel data) over a period from 1997 to 2007. Their econometric analysis shows that FDI inflows, particularly in the case of ASEAN, are associated with higher economic growth and there is a close relationship between the growth in average income and growth of income of the poor. In their sample for ASEAN, on average, about $40 \%$ of the effects of FDI on poverty reduction from economic growth and the remaining $60 \%$ are directly related, so the results show a positive association between FDI and reduction poverty

In the same way, Calvo and Hernandez (2006) examine the effects of FDI on poverty in 20 American Country between 1984 and 1998. Based on panel data, the authors used two dependent variables: the actual and the poverty gap. They found that the benefits of FDI vary the initial local conditions and orientation of the foreign subsidiary. They found that FDI reduce poverty on a global level. If foreign capital has doubled, the number of poor declined.

As for Nunnenkamp et al. (2007) use the CGE analysis to examine the effects ofFDI Poverty in Bolivia. The authors used a model of a modified version of general equilibrium which had 11 production sectors, 7 factors, and 6 types of households. The simulation results showed that FDI improves economic growth and reduced poverty. Other results showed that FDI generally widen income disparities between urban and rural areas and, in particular, led to increased employment and remuneration of the factors in urban areas.

Moreover, Reiter and Steensma (2010) conduct a study on the relationship between human development captured by the human development index (HDI), and FDI in a sample of 49 developing countries between 1980 and 2005 . The sample consists of a panel data set of 49 developing countries over the period 1980-2005, the authors use the method of unbalanced panel data. The results were consistent with the results of Jalilian and Weiss (2002). The 
relationship between FDI and improving human development is also more strongly positive when corruption is low. So the results show a positive association between FDI and poverty reduction.

Moreover, Zaman et al. (2012) have attempted to assess the impact of FDI on poverty reduction in Pakistan. They took time series data over a period of 26 years (1985-2011) based on a multi varied regression framework. . OLS estimates of the results showed a coefficient of FDI, implying that the increase in FDI will result in poverty reduction .They have concluded a positive link between FDI and poverty reduction in Pakistan.

Mahmood and Chaudhary (2012) also study the contribution of FDI to the reduction of poverty, lhe authors use the model of ARDL in Pakistan between 1973 and 2003.L'étude is the long-term relationship, short-term in the model. Government spending on health and education as well as the rate of economic growth have significant negative effects on poverty. The IDE helps therefore to reduce the level of poverty in Pakistan.

Meanwhile, Shamim et al. (2014) empirically analyze the relationship between FDI and poverty reduction in Pakistan. The period covered by this study was 1973-2011, the model used is the technique of time series data cointegration (time series data cointegration tehnique). The results showed that there was a positive relationship between FDI and reduction poverty, as Fowowe and Shuaibu (2014) and Jalilian and Weiss (2002).

Ucal (2014) also assess the relationship between foreign direct investment (FDI) and poverty to the macro-way in some developing countries. In this study, the author considers the unbalanced panel data method 26 countries in UNCTAD over a period of 24 years between 1990 and 2009. The results show that there is a statistically significant relationship between FDI and poverty. It is obvious that FDI reduces poverty in some developing countries.

Besides, Bharadwaj (2014) studies the relationship between globalization and poverty, the impact of real and financial integration on the counting rate and the poverty gap. In the study, FDI was used as indicator of globalization, while the population ratio and the poverty gap are indicated poverty Using a regression in 35 countries in the process of panel data development from 1990 to 2004, Baradwaj (2014) shows that the growth and the opening of GDP per capita are beneficial for the poor and FDI was considered beneficial for reducing poverty in countries in the sample.

In parallel, Uttama (2015) studies the relationship between FDI and the reduction of poverty. The data set includes transnational observations for six member countries of ASEAN (Indonesia, Malaysia, Philippines, Singapore, Thailand and Vietnam) during the period 1995-2011 using the technique of spatial panel data model, The analyzes confirm the significant positive relationship between FDI and poverty reduction in ASEAN, both individually and space.

\section{Empirical Methodology}

In our paper, we will use the model developed by Im and McLaren (2015) to study the impact of FDI on poverty in the countries of North Africa. The model used was as follows:

$$
P O V=f(I D E, V)
$$

Where POV poverty measure for each country, FDI measure foreign direct investment and V represents a vector of control variables. Thus, the control variables, the growth rate of gross domestic product (GDP), youth literacy rate (TAJ), financial development measured by domestic credit to the private sector (DF), the urban population (PU ), government spending (DEP) Market capitalization of listed companies (CBEC), the consumption or use of energy (EU), the inflation rate (INF), energy use renouvlable (CER), the gross capital formation (BCF) and the unemployment rate $(\mathrm{CH})$.

Note that poverty is measured by three indicators:

- The GINI index.

- The poverty gap at $\$ 1.91$.

- The poverty gap of $\$ 3.1$.

FDI is measured by the level of FDI to GDP for each country.

The models to estimate are: 


$$
\begin{aligned}
& L{ } I N I_{i t}=\beta_{0}+\beta_{1} L I D E_{i t}+\beta_{2} L C O 2_{i t}+\beta_{3} L I N F_{i t}+\beta_{4} L P I B_{i t}+\beta_{5} L P U_{i t} \\
& +\beta_{6} L T A J_{i t}+\beta_{7} L U E_{i t}+\beta_{8} L D E P_{i t}+\beta_{9} L D E F_{i t}+\beta_{10} L F B C_{i t} \\
& +\beta_{11} L C H_{i t}+\beta_{12} L C E R_{i t}+\beta_{13} L C B E C_{i t}+\varepsilon_{i t} \\
& L P O V 1.91 \$_{i t}=\beta_{0}+\beta_{1} L I D E_{i t}+\beta_{2} L C O 2_{i t}+\beta_{3} L I N F_{i t}+\beta_{4} L P I B_{i t}+\beta_{5} L P U_{i t} \\
& +\beta_{6} L T A J_{i t}+\beta_{7} L U E_{i t}+\beta_{8} L D E P_{i t}+\beta_{9} L D E F_{i t}+\beta_{10} L F B C_{i t} \\
& +\beta_{11} L C H_{i t}+\beta_{12} L C E R_{i t}+\beta_{13} L C B E C_{i t}+\varepsilon_{i t} \\
& L P O V 3.1 \$_{i t}=\beta_{0}+\beta_{1} L I D E_{i t}+\beta_{2} L C O 2_{i t}+\beta_{3} L I N F_{i t}+\beta_{4} L P I B_{i t}+\beta_{5} L P U_{i t} \\
& +\beta_{6} L T A J_{i t}+\beta_{7} L U E_{i t}+\beta_{8} L D E P_{i t}+\beta_{9} L D E F_{i t}+\beta_{10} L F B C_{i t} \\
& +\beta_{11} L C H_{i t}+\beta_{12} L C E R_{i t}+\beta_{13} L C B E C_{i t}+\varepsilon_{i t}
\end{aligned}
$$

\begin{tabular}{|c|c|c|c|}
\hline Nature of factor & The variable & Code Variable & Source \\
\hline $\begin{array}{l}\text { Dependent } \\
\text { variable }\end{array}$ & GINI Index & GINI & world Bank \\
\hline $\begin{array}{l}\text { Dependent } \\
\text { variable }\end{array}$ & Poverty to $\$ 1.90$ a day (2011 PPP) (\%) & \$ POV1.91 & world Bank \\
\hline $\begin{array}{l}\text { Dependent } \\
\text { variable }\end{array}$ & Poverty to $\$ 3.10$ a day (2011 PPP) (\%) & \$ POV3.1 & world Bank \\
\hline Control variable & $\mathrm{CO} 2$ emissions $(\mathrm{kt})$ & $\mathrm{CO} 2$ & world Bank \\
\hline Control variable & Foreign direct investment, net inflows (\% of GDP) & FDI & world Bank \\
\hline Control variable & Youth literacy rate (\% of youth aged 15 to 24 ) & TAJ & world Bank \\
\hline Control variable & GDP per capita (annual\%) & GDP & world Bank \\
\hline Control variable & Public expenditure (\% of GDP) & DEP & world Bank \\
\hline Control variable & $\begin{array}{l}\text { Use of renewable energy (\% of total energy } \\
\text { consumed) }\end{array}$ & CER & world Bank \\
\hline Control variable & Inflation, consumer prices (annual\%) & INF & world Bank \\
\hline Control variable & urban population (\% of total) & PU & world Bank \\
\hline Control variable & $\begin{array}{l}\text { Market capitalization of listed companies (\% of } \\
\text { GDP) }\end{array}$ & CBEC & world Bank \\
\hline Control variable & $\begin{array}{l}\text { Unemployment, total (\% of population) (ILO } \\
\text { modeled estimate) }\end{array}$ & $\mathrm{CH}$ & world Bank \\
\hline Control variable & Gross capital formation (\% of GDP) & $\mathrm{FBC}$ & world Bank \\
\hline Control variable & Domestic credit to private sector (\% of GDP) & DF & world Bank \\
\hline Control variable & $\begin{array}{l}\text { Energy use (kg oil equivalent) per \$ 1,000 GDP (PPP } \\
\text { constant 2011) }\end{array}$ & EU & world Bank \\
\hline
\end{tabular}

Or, $\beta_{0}$ is a constant, $\beta_{i}$ are coefficients of the explanatory variables $\mathrm{i}=1, \ldots, 13$ and $\varepsilon_{i t}$ it is the term of error.

Table 1 summarizes the different variables used in our paper.

Table 1. The variables

The data used in this paper are of annual frequency for all variables. These data come from the World Bank database and the International Monetary Fund for the period from 1985 to 2015 .We will estimate the models chosen by referring to an analysis of panel data.

The choice of panel data is based on the two dimensions of the data used; the first dimension is time (a period of 31 years) and the second is individual (employee sample consists of 6 countries of North Africa).

\section{Data}

In this section, we present the sample and the model used in our paper. Our objective in this paper, Is the study of the impact of FDI on poverty in the case of the North African country during the study period between 1985 and 2015.

In Table 2, we exposed the different countries in our paper. 
Table 2. The countries of North Africa

\begin{tabular}{lrrr}
\hline Name of country & Area $(\mathrm{km})$ & Population $(2016$ estimate) & Population density $\left(\right.$ per km $\left.{ }^{2}\right)$ \\
\hline Algeria & 2381741 & $37,100,000$ & 14.5 \\
Egypt & 1001450 & $81,249,302$ & 80.4 \\
Libya & 1759540 & 6461450 & 3.7 \\
Morocco & 710850 & $32,245,000$ & 70.8 \\
Sudan & 1886068 & 31957965 & 16.9 \\
Tunisia & 163610 & 10673000 & 64.7 \\
\hline
\end{tabular}

In this section we will try to make a descriptive analysis of the different results for the study the impact of FDI on poverty in the countries of North Africa.

First, let's define the type of assessment which is a regression on panel data. Our choice is justified by the presence of two dimensions in the data used; is the first time (a period of 31 years) and the second is individual (our sample is made up of 6 countries of North Africa).

This section is dedicated to the interpretation of results for the descriptive statistics and Pearson correlation matrix for the variables used in our paper.

All of the descriptive statistics of the variables used in our paper are summarized in Table 3.

Table 3. Descriptive statistics

\begin{tabular}{|c|c|c|c|c|c|c|c|c|}
\hline & LGINI & \$ LPOV1_91 & \$ LPOV3_1 & $\mathrm{LCO} 2$ & LIDE & LINF & LPIB & LPU \\
\hline Average & 3.659430 & 1.711339 & 2.819903 & 10.52246 & 1.740903 & 12.13125 & 1.966823 & 3.953845 \\
\hline Median & 3.572328 & 1.751173 & 2.913658 & 10.57184 & 1.226897 & 5.737290 & 1.894978 & 4.005441 \\
\hline Maximum & 4.146937 & 3.801985 & 4.074482 & 12.30497 & 9.424248 & 132.8238 & 104.6576 & 4.361301 \\
\hline Minimum & 3.425890 & -0.916291 & 0.741937 & 7.975197 & -0.469340 & -9.797647 & -62.21435 & 3.132751 \\
\hline Standard & 0.192268 & 1.537783 & 1.007091 & 1.022934 & 1.875266 & 21.34465 & 9.915128 & 0.299145 \\
\hline \multicolumn{9}{|l|}{ Deviation } \\
\hline skewness & 1.017615 & -0.314673 & -0.407684 & -0.437984 & 1.658814 & 3.792586 & 4.340137 & -0.572764 \\
\hline kurtosis & 3.330697 & 1.869836 & 1.860567 & 2.615518 & 6.371119 & 18.51450 & 72.66292 & 2.511294 \\
\hline Jarque-Bera & $32.94928 *$ & $12.96843 *$ & $15.21429 *$ & $7.092390 *$ & $173.3760 *$ & $2311.317 *$ & $38194.09 *$ & $12.02076 *$ \\
\hline Probability & 0.000000 & 0.001527 & 0.000497 & 0.028834 & 0.000000 & 0.000000 & 0.000000 & 0.002453 \\
\hline Sum & 680.6540 & 318.3091 & 524.5020 & 1957.178 & 323.8080 & 2256.413 & 365.8290 & 735.4151 \\
\hline Sum Sq. Dev. & 6.838913 & 437.4836 & 187.6328 & 193.5830 & 650.5753 & 84284.89 & 18187.31 & 16.55519 \\
\hline \multirow[t]{2}{*}{ observations } & 186 & 186 & 186 & 186 & 186 & 186 & 186 & 186 \\
\hline & LTAJ & LUE & LDEP & LDF & LFBC & CHL & LCER & LCBEC \\
\hline Average & 4.397266 & 4.647219 & 2.760326 & 3.117432 & 24.17608 & 2.671726 & 1.880000 & 3.329833 \\
\hline Median & 4.400727 & 4.538225 & 3.187676 & 3.306042 & 24.53558 & 2.694627 & 2.356580 & 3.180049 \\
\hline Maximum & 4.604464 & 5.460651 & 3.566570 & 4.336893 & 46.87646 & 3.394508 & 4.450014 & 5.622575 \\
\hline Minimum & 4.067913 & 4.276705 & 1.401579 & 0.479664 & 4.329239 & 2.091864 & -1.730354 & 0.716136 \\
\hline Standard & 0.148325 & 0.288363 & 0.742070 & 0.959663 & 7.523842 & 0.292898 & 1.737291 & 1.399367 \\
\hline \multicolumn{9}{|l|}{ Deviation } \\
\hline skewness & -0.428835 & 1.298344 & -0.776126 & -0.727663 & 0.207327 & 0.045106 & -0.529717 & -0.324575 \\
\hline kurtosis & 2.526260 & 3.880495 & 1.924430 & 2.732941 & 3.446433 & 2.417982 & 2.494614 & 2.045393 \\
\hline \multirow[t]{2}{*}{ Jarque-Bera } & 7.440210 & $58.26498 *$ & $27.63912 *$ & $16.96701 *$ & 200.877117 & 232.688345 & $10.67806 *$ & $10.32820 *$ \\
\hline & $* *$ & & & & & & & \\
\hline Probability & 0.024231 & 0.000000 & 0.000001 & 0.000207 & 0.000000 & 0.000000 & 0.004801 & 0.005718 \\
\hline Sum & 817.8915 & 864.3827 & 513.4206 & 579.8423 & 4496.752 & 496.9410 & 349.6800 & 619.3490 \\
\hline Sum Sq. Dev. & 4.070076 & 15.38337 & 101.8735 & 170.3764 & 10472.52 & 15.87098 & 558.3630 & 362.2723 \\
\hline observations & 186 & 186 & 186 & 186 & 186 & 186 & 186 & 186 \\
\hline
\end{tabular}

According to the results of Table 3, we found that the LCO2 variable, which expresses logarithm of CO2 emissions, can reach a maximum value of 12.30497 . As its minimum value is 7.975197 . Its risk is measured by the standard deviation is 1.022934 . 
The LGINI variable, which measures the logarithm of the GINI index, can reach a maximum value of 4.146937. While its minimum value is 3.425890 . Its risk is measured by the standard deviation is 0.192268 .

The variable \$ LPOV1_91, which measures the logarithm of the gap of poverty threshold of \$1.91 may reach a maximum value of 3.801985 . As its minimum value is -0.916291 . Its risk is measured by the standard deviation is 1.537783.

The variable \$ LPOV3_1, which measures the logarithm of the poverty gap at \$ 3.1 threshold, can reach a maximum value of 4.074482 . As its minimum value is 0.741937 . Its risk is measured by the standard deviation is 1.007091.

Both statistics of asymmetry (skewness) and kurtosis (kurtosis), we can conclude that all variables used in this paper are characterized by non-normal distribution. Then the asymmetry coefficients indicate that all variables are shifted to the left (negative sign of asymmetry coefficients) and is far from symmetrical except for LGINI variables, LIDE, LINF, LPIB, READ, LFBC, LCH, LCER LCBEC and which are oriented to the right (positive sign of asymmetry coefficients).

Also, the kurtosis coefficient shows that leptokurtic for all variables used in this paper indicate the presence of a high peak or a large tail in their volatilities (leptokurtic the coefficients are greater than 1).

In addition, the positive sign of estimation coefficients of Jarque-Bera statistics indicates that we can reject the null hypothesis of the normal distribution of the variables used in our paper. In fact, the high value of the coefficients of the Jarque-Bera statistic reflects the series are not normally distributed at a level of 1 percent.

The results shown by the three skew statistics, kurtosis and Jarque-Bera suggest that all variables used in our paper are not normally distributed for the case of the countries of North Africa and during the study period from 1985 to 2015.

Thus, we conducted a test of the correlation between the different variables used in the case of the North African country during the study period from 1985 to 2015. Table 4 summarizes the results for test Pearson correlation.

In addition, the results showed that all coefficients between the explanatory variables do not exceed the tolerance limit (0.7), which does not cause problems in the estimation of the model. That is to say, we can integrate the different variables used in the same model.

Table 4. The correlation matrix

\begin{tabular}{|c|c|c|c|c|c|c|c|c|}
\hline & LGINI & \$ LPOV1_91 & \$ LPOV3_1 & $\mathrm{LCO} 2$ & LIDE & LINF & LPIB & LPU \\
\hline LGINI & 1.000000 & 0.216744 & 0.154968 & -0.165647 & -0.220977 & -0.227902 & -0.017152 & 0.653434 \\
\hline \$ LPOV1_91 & 0.216744 & 1.000000 & 0.089412 & 0.399300 & -0.211419 & 0.025710 & -0.059185 & 0.176666 \\
\hline \$ LPOV3_1 & 0.154968 & 0.089412 & 1.000000 & 0.457670 & -0.226173 & 0.013915 & -0.057560 & 0.144844 \\
\hline $\mathrm{LCO} 2$ & -0.165647 & 0.399300 & 0.457670 & 1.000000 & 0.000554 & -0.472189 & -0.028778 & 0.416057 \\
\hline LIDE & -0.220977 & -0.211419 & -0.226173 & 0.000554 & 1.000000 & -0.175203 & 0.107440 & -0.116444 \\
\hline LINF & -0.227902 & 0.025710 & 0.013915 & -0.472189 & -0.175203 & 1.000000 & -0.034212 & -0.550643 \\
\hline LPIB & -0.017152 & -0.059185 & -0.057560 & -0.028778 & 0.107440 & -0.034212 & 1.000000 & -0.022537 \\
\hline LPU & 0.653434 & 0.176666 & 0.144844 & 0.416057 & -0.116444 & -0.550643 & -0.022537 & 1.000000 \\
\hline LTAJ & 0.526538 & 0.287783 & 0.208722 & 0.066702 & 0.093524 & -0.139248 & -0.014518 & 0.535036 \\
\hline LUE & 0.274596 & 0.255015 & 0.194614 & -0.655195 & -0.074166 & 0.565342 & -0.090298 & -0.340264 \\
\hline LDEP & -0.622753 & -0.437272 & -0.386163 & 0.404099 & 0.115025 & -0.256776 & -0.007249 & 0.011678 \\
\hline LDF & 0.057127 & -0.258985 & -0.274410 & 0.330278 & 0.061514 & -0.508943 & -0.049271 & 0.390001 \\
\hline LFBC & -0.167209 & -0.192547 & -0.163840 & 0.278071 & 0.174104 & -0.297027 & -0.008009 & 0.278378 \\
\hline CHL & 0.478501 & 0.349806 & 0.310655 & -0.192702 & -0.311803 & 0.043348 & -0.046815 & 0.281923 \\
\hline LCER & -0.160403 & -0.551713 & -0.579122 & -0.017235 & 0.273491 & 0.341804 & 0.070820 & -0.627556 \\
\hline \multirow[t]{2}{*}{ LCBEC } & -0.467603 & -0.061890 & 0.025036 & 0.622213 & -0.079906 & -0.251845 & -0.017867 & 0.102219 \\
\hline & LTAJ & LUE & LDEP & LDF & LFBC & CHL & LCER & LCBEC \\
\hline GINI & 0.526538 & 0.274596 & -0.622753 & 0.057127 & -0.167209 & 0.478501 & -0.160403 & -0.467603 \\
\hline \$ POV1_91 & 0.287783 & 0.255015 & -0.437272 & -0.258985 & -0.192547 & 0.349806 & -0.551713 & -0.061890 \\
\hline \$ POV3_1 & 0.208722 & 0.194614 & -0.386163 & -0.274410 & -0.163840 & 0.310655 & -0.579122 & 0.025036 \\
\hline $\mathrm{CO} 2$ & 0.066702 & -0.655195 & 0.404099 & 0.330278 & 0.278071 & -0.192702 & -0.017235 & 0.622213 \\
\hline FDI & 0.093524 & -0.074166 & 0.115025 & 0.061514 & 0.174104 & -0.311803 & 0.273491 & -0.079906 \\
\hline INF & -0.139248 & 0.565342 & -0.256776 & -0.508943 & -0.297027 & 0.043348 & 0.341804 & -0.251845 \\
\hline
\end{tabular}




\begin{tabular}{lllllllll}
\hline GDP & -0.014518 & -0.090298 & -0.007249 & -0.049271 & -0.008009 & -0.046815 & 0.070820 & -0.017867 \\
COULD & 0.535036 & -0.340264 & 0.011678 & 0.390001 & 0.278378 & 0.281923 & -0.627556 & 0.102219 \\
TAJ & 1.000000 & 0.287557 & -0.393472 & 0.034387 & -0.101385 & 0.309117 & -0.278047 & -0.444202 \\
EU & 0.287557 & 1.000000 & -0.038724 & -0.542902 & -0.515000 & 0.271294 & 0.379276 & -0.029952 \\
DEP & -0.393472 & -0.038724 & 1.000000 & 0.538695 & 0.485806 & -0.438228 & -0.139890 & 0.011836 \\
DF & 0.034387 & -0.542902 & 0.538695 & 1.000000 & 0.167907 & -0.338843 & -0.085541 & 0.181762 \\
FBC & -0.101385 & -0.515000 & 0.485806 & 0.167907 & 1.000000 & -0.180540 & -0.400536 & 0.556466 \\
CH & 0.309117 & 0.271294 & -0.438228 & -0.338843 & -0.180540 & 1.000000 & -0.331089 & -0.283439 \\
RECs & -0.278047 & 0.379276 & -0.139890 & -0.085541 & -0.400536 & -0.331089 & 1.000000 & -0.489024 \\
CBEC & -0.444202 & -0.029952 & 0.011836 & 0.181762 & 0.556466 & -0.283439 & -0.489024 & 1.000000 \\
\hline
\end{tabular}

A study of the causal relationship between FDI and poverty in the countries of North Africa requires prior perform stationary tests to determine the order of integration of each series. The results of the Levin-Lin-Chu test (LLC), Im-Pesaran-Shin (IPS), ADF and Fisher-PP-Fisher applied to the series are shown in Table 5 for the countries of the North Africa.

Acceptance or rejection of the null hypothesis of the different tests is based on the value of probability and the indicated test statistics. These probabilities are compared with a $10 \%$ threshold. If these probabilities are less than $10 \%$, then we reject the null hypothesis and if these probabilities are greater than $10 \%$, then we accept the null hypothesis.

For the countries of North Africa and in Table 5, we observed that only two variables LIDE, LPIB and LUE are non-stationary in level according to the test of Levin-Lin-Chu but all variables are stationary in difference first according to this test.

According to statistics of the test-Im Pesaran-Shin (IPS) test ADF-Fisher and the test of PP-Fisher, we can conclude that only four variables LIDE, LPIB, LINF and LUE are stationary in level. But first difference, all variables are stationary according to these three tests. Thereafter, all the variables are integrated of order 1 . Thus, we can use the cointegration test.

Table 5. The unit root test

\begin{tabular}{|c|c|c|c|c|c|c|c|c|}
\hline & \multicolumn{2}{|c|}{ Levin, Lin and Chu test } & \multicolumn{2}{|c|}{ Im Pesaran and Shin test } & \multicolumn{2}{|c|}{ Fisher-ADF test } & \multicolumn{2}{|c|}{ Fisher-PP test } \\
\hline & in level & $\begin{array}{l}\text { In the first } \\
\text { difference }\end{array}$ & in level & $\begin{array}{l}\text { In the first } \\
\text { difference }\end{array}$ & in level & $\begin{array}{l}\text { In the first } \\
\text { difference }\end{array}$ & in level & $\begin{array}{l}\text { In the first } \\
\text { difference }\end{array}$ \\
\hline LGINI & 0.04843 & $-8.49929 *$ & 0.89018 & $-8.20229 *$ & 2.29937 & $* 60.0539$ & 2.40167 & * 55.2620 \\
\hline \$ LPOV1_91 & -0.14884 & $-5.74166 *$ & 1.42407 & $-4.50321 *$ & 3.24554 & $* 30.8073$ & 3.11444 & $* 62.9879$ \\
\hline \$ LPOV3_1 & 0.16586 & $-6.66453 *$ & 1.83580 & $-5.19057 *$ & 2.70321 & $* 40.9005$ & 2.59457 & $* 75.6234$ \\
\hline $\mathrm{LCO} 2$ & $-2.31532 * *$ & $-4.30995 *$ & 0.69587 & $-7.07982 *$ & 8.56954 & $* 69.5309$ & 9.67859 & $154030 *$ \\
\hline \multirow[t]{2}{*}{ LIDE } & $-1.34558 * * *$ & $-7.74929 *$ & & & & & 21.3662 & \\
\hline & & & $-1.45050 * * *$ & $-7.72450 *$ & 17.4511 & $* 77.2053$ & $* *$ & $110975 *$ \\
\hline \multirow[t]{2}{*}{ LINF } & -0.95540 & $-4.66477 *$ & & & & & 19.9673 & \\
\hline & & & -1.15735 & $-8.10519 *$ & 15.8569 & $* 80.9894$ & $* * *$ & $169770 *$ \\
\hline \multirow[t]{2}{*}{ LPIB } & $-1.51908 * * *$ & $-8.99655 *$ & & & $*$ & & 114075 & \\
\hline & & & $-6.75610 *$ & $-15.2398 *$ & 69.8560 & $143243 *$ & $*$ & $147112 *$ \\
\hline LPU & 0.27789 & $-3.04947 *$ & 1.41163 & $-2.65498 *$ & 8.52763 & * 38.9532 & 5.71631 & $* 96.0690$ \\
\hline LTAJ & 0.92601 & $-6.17024 *$ & 2.71270 & $-5.34750 *$ & 1.70601 & $* 42.3096$ & 1.56592 & $* 82.1910$ \\
\hline \multirow[t]{2}{*}{ LUE } & 0.94164 & $-6.57636 *$ & & & & $* 74.3314$ & 20.9092 & $166572 *$ \\
\hline & & & 0.52071 & $-7.52213 *$ & 11.7411 & & $* * *$ & \\
\hline LDEP & 0.10824 & $-4.94802 *$ & 0.78000 & $-4.79169 *$ & 6.71074 & * 37.6871 & 6.01183 & * 74.3079 \\
\hline LDF & -0.45709 & $-2.94146 *$ & 0.07851 & $-4.68708 *$ & 8.62522 & $* 47.3625$ & 8.09243 & $* 87.9162$ \\
\hline LFBC & -0.55114 & $-8.91245 *$ & -0.27310 & $-8.55507 *$ & 12.4720 & $* 86.1683$ & 12.9794 & $109564 *$ \\
\hline CHL & 1.16977 & $-8.14926 *$ & 0.72209 & $-3.48922 *$ & 6.58552 & $* 36.7939$ & 9.46106 & $104902 *$ \\
\hline LCER & 0.35985 & $-6.81112 *$ & 1.81424 & $-7.27592 *$ & 4.81480 & $* 73.3678$ & 4.84895 & $145911 *$ \\
\hline LCBEC & 1.40710 & $-4.90207 *$ & 0.84712 & $-6.38119 *$ & 8.13605 & $* 62.8924$ & 12.1554 & $118134 *$ \\
\hline
\end{tabular}

Note: In this test, the p-value is compared to $10 \%$. If the probabilities $<10 \%$ therefore we reject the null hypothesis and the probabilities> $10 \%$ then we accept the null hypothesis. With the null hypothesis all series are non-stationary. $(*),(* *)$ and $(* * *)$ are significant values for the $1 \%$ and $5 \%$ respectively. 


\section{Empirical Analysis}

\subsection{The Cointegration Test}

We will present in this part of the test results of cointegration. Kao tests, Pedroni and Johenson Fisher cointegration are applied to ensure the long-term relationship between the variables used in this paper to examine the impact of FDI on poverty for countries of North Africa.

The Kao test is based on the statistical t-test and ADF Pedroni is based on two statistical Panel and Panel-ADFPP individual and grouped. But Fisher's test is based on the Fisher statistical test track and Fisher Statistic of maxeigen test. The results of cointegration test for the countries of North Africa are shown in Tables 6, 7 and 8 .

Indeed, the Pedroni test demonstrates the long-term relationship between FDI and poverty indicators. Thus, Kao test confirms the long term relationship between the different variables used in our paper mainly between FDI and poverty indicators. In addition, Fisher's test results confirm the presence of a long-term link between FDI and poverty in the countries of North Africa for the study period from 1985 to 2015.

According to the results of the two tables 6, 7 and 8, we have certified the existence of a cointegration relationship between the different series studied in our paper. Indeed, the result of the null hypothesis test of no cointegration was rejected at the 5\% threshold, which explains the presence of a cointegration relationship. The results of these tests can determine the use of an error correction model. Also, to test the effect of FDI on poverty in the countries of North Africa, we will perform a FMOLS estimate.

Table 6. The test cointegration the impact of FDI on poverty (GINI) for the case of the countries of North Africa

\begin{tabular}{|c|c|c|c|c|c|c|c|c|}
\hline \multicolumn{4}{|c|}{ Pedroni Residual Cointegration Test } & \multirow{2}{*}{$\begin{array}{l}\text { Kao Residual } \\
\text { Cointegration } \\
\text { Test } \\
\text { Statistics } \\
\text { (Probability) }\end{array}$} & \multicolumn{4}{|c|}{ Fisher Johansen Cointegration Test Panel } \\
\hline \multicolumn{2}{|c|}{$\begin{array}{l}\text { Common AR coefs. (Within- } \\
\text { dimension) }\end{array}$} & \multicolumn{2}{|c|}{$\begin{array}{l}\text { Individual AR coefs. } \\
\text { (Between-dimension) }\end{array}$} & & $\begin{array}{l}\text { Fisher } \\
\text { Stat. * } \\
\text { (From test } \\
\text { track) }\end{array}$ & Prob. & $\begin{array}{l}\text { Fisher } \\
\text { Stat. * } \\
\text { (From } \\
\text { max- } \\
\text { eigen test) }\end{array}$ & Prob. \\
\hline PP-Stati & & PP-Statistic & -9.409036 & -7.486544 & 777.3 & $(0.0000) *$ & 778.3 & $(0.0000) *$ \\
\hline Panel & -8.643537 & Panel & $(0.0000) *$ & $(0.0000) *$ & & & & \\
\hline ADF- & $(0.0000) *$ & ADF- & -8.509099 & & & & & \\
\hline Statistic & -9.281424 & Statistic & $(0.0000) *$ & & & & & \\
\hline Panel & $(0.0000) *$ & Panel & & & & & & \\
\hline
\end{tabular}

Note: $(*)$ are significant values at a threshold of $1 \%$.

Table 7. The test cointegration the impact of FDI on poverty (\$ POV1_91) for the case of the countries of North Africa

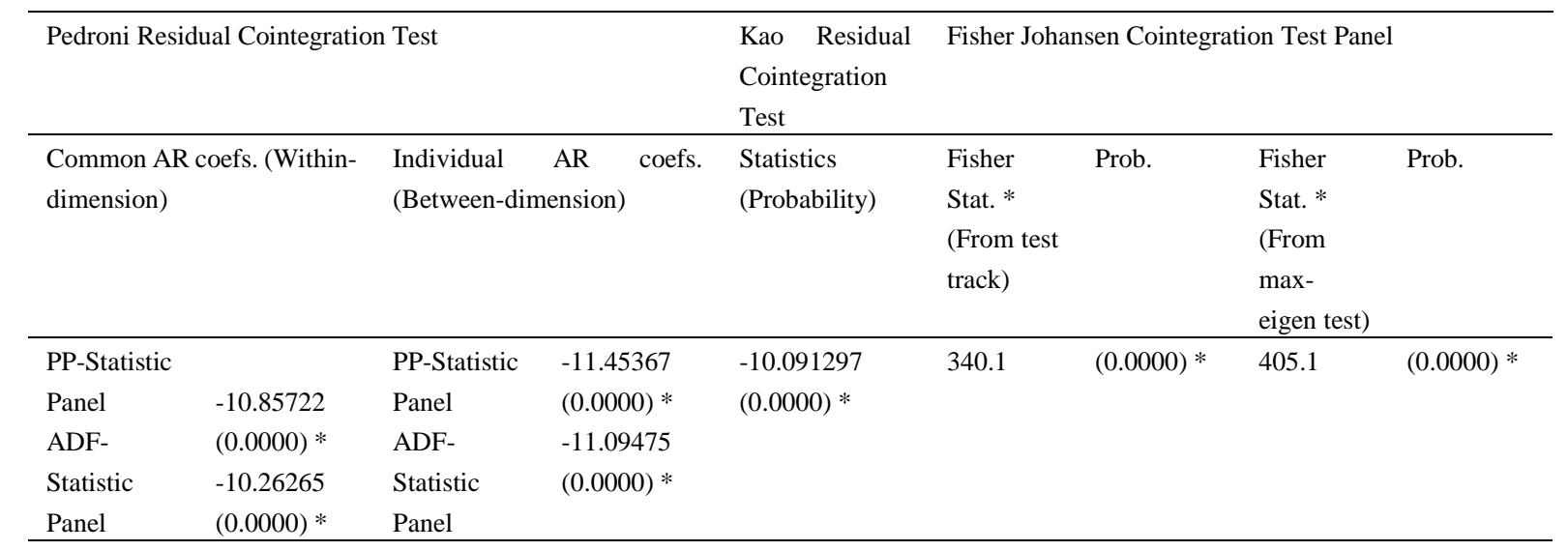

Note: $(*)$ are significant values at a threshold of $1 \%$. 
Table 8. The test cointegration the impact of FDI on poverty (\$POV3_1) for the case of the countries of North Africa

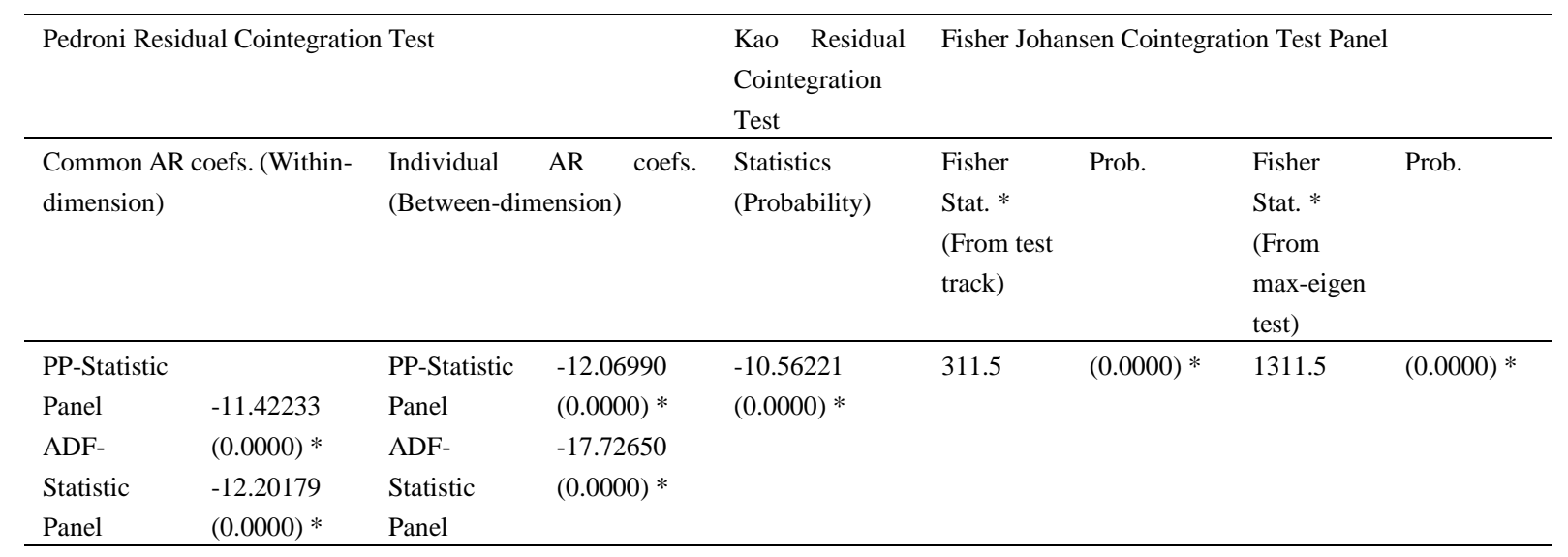

Note: $\left(^{*}\right)$ are significant values at a threshold of $1 \%$.

\subsection{The Estimation Results FMOLS}

The panel FMOLS method proposed by Pedroni $(1996,2000)$ solves problems of heterogeneity in the sense that it allows the use of heterogeneous cointegrating vectors. For Maeso-Fernandez et al. (2004), FMOLS estimator takes into account the presence of the constant term and the possible existence of correlation between the error term and differences estimators.

Adjustments are made to this effect on the dependent variable and long-term parameters obtained by estimating the fitted equation. In the case of panel data, the long-term coefficients from the FMOLS art are obtained by the average group of estimators with respect to the sample size $(\mathrm{N})$.

In addition, the coefficients of determination for the two estimates are greater than 0.7 , therefore, the three estimated models are characterized by a good linear fit.

For FMOLS estimate of the first indicator of poverty, we noticed that there are eight significant variables, but with different signs (Table 9).

Table 9. Estimation FMOLS for variable LGINI

\begin{tabular}{lllll}
\hline Variable & Coefficient & Std. error & Does Statistic & Prob. \\
\hline LIDE & -0.007476 & 0.003124 & $-2.393038 * *$ & 0.0179 \\
LCO2 & 0.060745 & 0.032014 & $1.897425 * * *$ & 0.0596 \\
LINF & -0.000189 & 0.000302 & -0.626424 & 0.5319 \\
LPIB & 0.000605 & 0.000447 & 1.352522 & 0.1781 \\
LPU & 0.053411 & 0.118210 & 0.451830 & 0.6520 \\
LTAJ & -0.061336 & 0.085759 & -0.715211 & 0.4755 \\
LUE & 0.196829 & 0.051642 & $3.811434 *$ & 0.0002 \\
LDEP & -0.130498 & 0.044162 & $-2.954995 *$ & 0.0036 \\
LDF & 0.030973 & 0.009888 & $3.132484 *$ & 0.0021 \\
LFBC & 0.002445 & 0.001284 & $1.904263 * * *$ & 0.0587 \\
CHL & 0.075868 & 0.036236 & $2.093717 * *$ & 0.0379 \\
LCER & 0.006174 & 0.029475 & 0.209457 & 0.8344 \\
LCBEC & 0.030269 & 0.008532 & $3.547531 *$ & 0.0005 \\
R-squared & 0.965496 & & & \\
Adjusted R-squared & 0.961638 & & & \\
\hline
\end{tabular}

Note: $(*),(* *)$ and $(* * *)$ are significant values for the $1 \%, 5 \%$ and $10 \%$ respectively

We found that, statistically significant and positive at a $1 \%$ level. Noula LIDE variable measuring foreign direct investment has a negative impact on the Gini index to a threshold of 5\%. That is to say, if the level of FDI increased by 5 units, then the GINI index decreases by 0.007476 units. 
Indeed, $\mathrm{CO} 2$ emissions have a significant positive impact on the Gini index to a $10 \%$ threshold. This means that if $\mathrm{CO} 2$ emissions increase of 5 units while poverty increases 0.060745 units at time $t$ in the case of the North African country.

ECL variable which measures the level of energy consumption is statistically significant and positive at a $1 \%$ level. So if energy consumption increases by one then, poverty increases 0.196829 units.

We noticed, is statistically significant and positive at a $1 \%$ level. Noula LDEP variable measuring government spending has a negative impact on poverty as measured by the GINI index. That is to say, if the level of public spending increases of 10 units, then, poverty decreases by 0.130498 units.

So, we notice that the LDF variable that measures the financial development has a positive and significant impact on poverty at a threshold of $1 \%$. That is to say, if the level of financial development increases by one, then, poverty increases 0.030973 units.

The LFBC variable that measures the gross formation of capital stock also has a positive and significant impact on the Gini index to a threshold of $1 \%$. That is to say, if the level of gross fixed capital stock increases by one, then, poverty increases $0.002,445$ units.

CHL variable that measures the unemployment rate in each country is also positive and statistically significant at a threshold of 5\%. So if unemployment rate rises of five units then, poverty in the countries of North Africa increases 0.075868 units.

The LCBEC variable that measures the market capitalization of listed companies is statistically significant and positive at a $1 \%$ level. So if the market capitalization of listed companies increased by one then, poverty increases 0.030269 units.

For FMOLS estimate of the second indicator of poverty (\$ LPOV1_91), we noticed that there are four significant variables, but with different signs (Table 10).

We notice that the LTAJ variable that measures the youth literacy rate has a negative impact on poverty as measured by the poverty gap of \$ LPOV1_91. That is to say, if the youth literacy rate increased by 5 units, then the poverty gap decreases LPOV1_91 \$2.059331 units.

So we remark that the LDF variable that measures the financial development has a positive and significant impact on the poverty gap of \$ LPOV1_91 a threshold of 1\%. That is to say, if the level of financial development increases by one, then, poverty increases 0.384065 units.

The LFBC variable that measures the gross formation of capital stock also has a positive and significant impact on the poverty gap of \$ LPOV1_91 a threshold of 5\%. That is to say, if the level of gross fixed capital stock increases by five units, then the poverty gap increases by \$ LPOV1_910.028908 units.

CHL variable that measures the unemployment rate in each country is also positive and statistically significant at a threshold of 5\%. So if unemployment rate rises of five units then the poverty gap of \$ LPOV1_91 in the countries of North Africa increases 0.075868 units.

For FMOLS estimate of third indicator of poverty (\$ LPOV3_1), we noticed that there are four significant variables, but with different signs (Table 11).

We notice that the LTAJ variable that measures the youth literacy rate has a negative impact on poverty as measured by the poverty gap of \$ LPOV3_1. That is to say, if the youth literacy rate increased by 5 units, then the poverty gap decreases LPOV3_1 \$1.284032 units.

So we notice that the LDF variable measuring financial development has a positive and significant impact on the poverty gap of \$ LPOV3_1 a threshold of 5\%. That is to say, if the level of financial development increases of five units, then, poverty increases 0.169685 units.

The LFBC variable that measures the gross formation of capital stock was also a positive and significant impact on the poverty gap of \$ LPOV3_1 a threshold of 1\%. That is to say, if the level of gross fixed capital stock increases by one, then the poverty gap increases by $\$$ LPOV3_10.024755 units.

CHL variable that measures the unemployment rate in each country is also positive and statistically significant at a threshold of $1 \%$. So if unemployment rate rises by one while the poverty gap of \$ LPOV3_1 in the countries of North Africa increases 0.773105 units. 
Table 10. Estimated FMOLS for the variable \$ LPOV1_91

\begin{tabular}{lllll}
\hline Variable & Coefficient & Std. error & Does Statistic & Prob. \\
LIDE & -0.043698 & 0.034938 & -1.250710 & 0.2129 \\
LCO2 & -0.136463 & 0.358038 & -0.381142 & 0.7036 \\
LINF & 0.000880 & 0.003381 & 0.260174 & 0.7951 \\
LPIB & 0.005690 & 0.005001 & 1.137808 & 0.2569 \\
LPU & 0.846147 & 1.322026 & 0.640039 & 0.5231 \\
LTAJ & -2.059331 & 0.959096 & $-2.147157 * *$ & 0.0333 \\
LUE & 0.649806 & 0.577543 & 1.125121 & 0.2622 \\
LDEP & 0.313307 & 0.493891 & 0.634364 & 0.5267 \\
LDF & 0.384065 & 0.110582 & $3.473121 *$ & 0.0007 \\
LFBC & 0.028908 & 0.014357 & $2.013556 * *$ & 0.0457 \\
CHL & 1.185640 & 0.405251 & $2.925694 *$ & 0.0039 \\
LCER & 0.041089 & 0.329641 & 0.124649 & 0.9010 \\
LCBEC & 0.098474 & 0.095424 & 1.031962 & 0.3036 \\
R-squared & 0.936950 & & & \\
Adjusted R-squared & 0.929901 & & & \\
\hline
\end{tabular}

Note: $(*),(* *)$ and $(* * *)$ are significant values for the $1 \%, 5 \%$ and $10 \%$ respectively

Table 11. Estimated FMOLS for the variable \$ LPOV3_1

\begin{tabular}{lllll}
\hline Variable & Coefficient & Std. error & Does Statistic & Prob. \\
\hline LIDE & -0.036537 & 0.022739 & -1.606815 & 0.1101 \\
LCO2 & 0.000959 & 0.233022 & 0.004116 & 0.9967 \\
LINF & -0.000476 & 0.002200 & -0.216293 & 0.8290 \\
LPIB & 0.003442 & 0.003255 & 1.057469 & 0.2919 \\
LPU & -0.030729 & 0.860415 & -0.035714 & 0.9716 \\
LTAJ & -1.284032 & 0.624210 & $-2.057053 * *$ & 0.0413 \\
LUE & 0.515212 & 0.375883 & 1.370671 & 0.1724 \\
LDEP & -0.178584 & 0.321440 & -0.555577 & 0.5793 \\
LDF & 0.169685 & 0.071970 & $2.357706 * *$ & 0.0196 \\
LFBC & 0.024755 & 0.009344 & $2.649336 *$ & 0.0089 \\
CHL & 0.773105 & 0.263750 & $2.931206 *$ & 0.0039 \\
LCER & 0.000318 & 0.214541 & 0.001481 & 0.9988 \\
LCBEC & 0.070929 & 0.062105 & 1.142086 & 0.2551 \\
R-squared & 0.939816 & & & \\
Adjusted R-squared & 0.933088 & & & \\
\hline
\end{tabular}

Note: $(*),(* *)$ and $(* * *)$ are significant values for the $1 \%, 5 \%$ and $10 \%$ respectively

\subsection{The Causality Test}

We need to check if the IDE cause the movements of poverty or poverty because FDI in the countries of North Africa.

Acceptance or rejection of the null hypothesis of Granger causality test is based on a threshold of $5 \%$. If the probability of the test is less than $5 \%$ in this case we reject the null hypothesis and if the probability is greater than $5 \%$ then we accept the null hypothesis of no causality.

Tables 12, 13, and 14 summarize all the results of causality test for the three indicators of poverty for those countries of North Africa and the study period of 1985 to 2015.

According to Table 12, we noticed that there is a unidirectional relationship between the consumption of energy and poverty Granger $(0.9956>0.0102$ and $5 \%<5 \%)$. Only the GINI index can cause Granger consumption of energy.

Thus there is no causal relationship between the Gini index and other senses to control variables Granger as their probability values are greater than 0.05 , which allow accepting the null hypothesis of the test. 
Table 12 . The causality test for variable LGINI

\begin{tabular}{llll}
\hline Null Hypothesis: & Obs & F-Statistic & Prob. \\
\hline CO2 does not Granger Cause GINI & 174 & 0.02150 & 0.9787 \\
GINI does not Granger Cause CO2 & & 2.05242 & 0.1316 \\
FDI does not Granger Cause GINI & 174 & 0.06502 & 0.9371 \\
GINI does not Granger Cause IDE & & 1.40501 & 0.2482 \\
INF does not Granger Cause GINI & 174 & 0.16511 & 0.8479 \\
GINI does not Granger Cause INF & & 0.22829 & 0.7961 \\
GDP does not Granger Cause GINI & 174 & 0.05708 & 0.9445 \\
GINI does not Granger Cause GDP & & 1.45896 & 0.2354 \\
PU does not Granger Cause GINI & 174 & 0.00394 & 0.9961 \\
GINI does not Granger Cause PU & & 0.01741 & 0.9827 \\
TAJ does not Granger Cause GINI & 174 & 0.71878 & 0.4888 \\
GINI does not Granger Cause TAJ & & 0.02269 & 0.9776 \\
EU does not Granger Cause GINI & 174 & 0.00440 & 0.9956 \\
GINI does not Granger Cause EU & & 4.70942 & 0.0102 \\
DEP does not Granger Cause GINI & 174 & 0.92156 & 0.3999 \\
GINI does not Granger Cause DEP & & 0.07589 & 0.9270 \\
DF does not Granger Cause GINI & 174 & 0.30542 & 0.7372 \\
GINI does not Granger Cause DF & & 0.92725 & 0.3976 \\
BCF does not Granger Cause GINI & 174 & 0.41309 & 0.6623 \\
GINI does not Granger Cause FBC & & 1.46845 & 0.2332 \\
CH does not Granger Cause Gini & 174 & 0.03707 & 0.9636 \\
Gini does not Granger Cause CH & & 0.59528 & 0.5526 \\
REC does not Granger Cause GINI & 174 & 0.30342 & 0.7387 \\
GINI does not Granger Cause CER & & 0.30986 & 0.7340 \\
CBEC does not Granger Cause GINI & 174 & 0.87943 & 0.4169 \\
GINI does not Granger Cause CBEC & & 0.58106 & 0.5604 \\
\hline
\end{tabular}

According to Table 13, we noticed that there is no causal relationship between poverty gap to $\$ 1.91$ and the other control variables Granger as their probability values are greater than 0.05 , which allow accepting the null hypothesis of the test.

According to Table 14, we noticed that there is no causal relationship between poverty gap of $\$ 3.1$ and other control variables Granger as their probability values are greater than 0.05 , which allow accepting the null hypothesis of the test.

Table 13. The causality test for the variable \$ LPOV1_91

\begin{tabular}{llll}
\hline Null Hypothesis: & Obs & F-Statistic & Prob. \\
\hline CO2 does not Granger Cause \$ POV1_91 & 174 & 0.29971 & 0.7414 \\
\$ POV1_91 does not Granger Cause CO2 & & 0.41057 & 0.6639 \\
FDI does not Granger Cause \$ POV1_91 & 174 & 0.83992 & 0.4335 \\
\$ POV1_91 does not Granger Cause IDE & & 2.24868 & 0.1087 \\
INF does not Granger Cause \$ POV1_91 & 174 & 0.20629 & 0.8138 \\
\$POV1_91 does not Granger Cause INF & & 0.11658 & 0.8900 \\
GDP does not Granger Cause \$ POV1_91 & 174 & 0.25314 & 0.7767 \\
\$ POV1_91 does not Granger Cause GDP & & 1.04794 & 0.3529 \\
PU does not Granger Cause \$ POV1_91 & 174 & 0.21266 & 0.8086 \\
\$ POV1_91 does not Granger Cause PU & & 0.12238 & 0.8849 \\
TAJ does not Granger Cause \$ POV1_91 & 174 & 0.18553 & 0.8308 \\
\$ POV1_91 does not Granger Cause TAJ & & 0.76788 & 0.4656 \\
EU does not Granger Cause \$ POV1_91 & 174 & 0.71114 & 0.4925 \\
\$ POV1_91 does not Granger Cause EU & & 0.70694 & 0.4946 \\
DEP does not Granger Cause \$ POV1_91 & 174 & 2.11998 & 0.1232 \\
\$ POV1_91 does not Granger Cause DEP & & 0.92243 & 0.3995 \\
\hline
\end{tabular}




\begin{tabular}{lccc}
\hline DF does not Granger Cause \$ POV1_91 & 174 & 1.07477 & 0.3437 \\
\$ POV1_91 does not Granger Cause DF & & 1.78316 & 0.1713 \\
BCF does not Granger Cause \$ POV1_91 & 174 & 0.09534 & 0.9091 \\
\$ POV1_91 does not Granger Cause FBC & & 0.23879 & 0.7878 \\
CH does not Granger Cause \$ POV1_91 & 174 & 0.40424 & 0.6681 \\
\$ POV1_91 does not Granger Cause CH & & 0.42171 & 0.6566 \\
REC does not Granger Cause \$ POV1_91 & 174 & 0.00168 & 0.9983 \\
\$ POV1_91 does not Granger Cause CER & & 0.83364 & 0.4362 \\
CBEC does not Granger Cause \$ POV1_91 & \multirow{2}{*}{174} & 0.10968 & 0.8962 \\
\$ POV1_91 does not Granger Cause CBEC & & 0.06561 & 0.9365 \\
\hline
\end{tabular}

Table 14. The causality test for the variable \$ LPOV3_1

\begin{tabular}{|c|c|c|c|}
\hline Null Hypothesis: & Obs & F-Statistic & Prob. \\
\hline CO2 does not Granger Cause \$ POV3_1 & 174 & 0.27003 & 0.7637 \\
\hline \$ POV3_1 does not Granger Cause CO2 & & 0.25712 & 0.7736 \\
\hline FDI does not Granger Cause \$ POV3_1 & 174 & 1.02480 & 0.3611 \\
\hline \$ POV3_1 does not Granger Cause IDE & & 2.79780 & 0.0638 \\
\hline INF does not Granger Cause \$ POV3_1 & 174 & 0.33738 & 0.7141 \\
\hline \$ POV3_1 does not Granger Cause INF & & 0.04963 & 0.9516 \\
\hline GDP does not Granger Cause \$ POV3_1 & 174 & 0.17519 & 0.8395 \\
\hline \$ POV3_1 does not Granger Cause GDP & & 0.97517 & 0.3792 \\
\hline PU does not Granger Cause \$ POV3_1 & 174 & 0.65283 & 0.5219 \\
\hline \$ POV3_1 does not Granger Cause PU & & 0.13932 & 0.8701 \\
\hline TAJ does not Granger Cause \$ POV3_1 & 174 & 1.10604 & 0.3332 \\
\hline \$ POV3_1 does not Granger Cause TAJ & & 0.45709 & 0.6339 \\
\hline EU does not Granger Cause \$ POV3_1 & 174 & 0.67018 & 0.5130 \\
\hline \$ POV3_1 does not Granger Cause EU & & 0.68672 & 0.5046 \\
\hline DEP does not Granger Cause \$ POV3_1 & 174 & 1.52760 & 0.2200 \\
\hline \$ POV3_1 does not Granger Cause DEP & & 0.48908 & 0.6141 \\
\hline DF does not Granger Cause \$ POV3_1 & 174 & 1.24358 & 0.2910 \\
\hline \$ POV3_1 does not Granger Cause DF & & 1.60294 & 0.2043 \\
\hline BCF does not Granger Cause $\$$ POV3_1 & 174 & 0.01918 & 0.9810 \\
\hline \$ POV3_1 does not Granger Cause FBC & & 0.19131 & 0.8261 \\
\hline CH does not Granger Cause \$ POV3_1 & 174 & 0.68399 & 0.5060 \\
\hline \$ POV3_1 does not Granger Cause CH & & 0.48737 & 0.6151 \\
\hline REC does not Granger Cause $\$$ POV3_1 & 174 & 0.08870 & 0.9152 \\
\hline \$ POV3_1 does not Granger Cause CER & & 0.17997 & 0.8355 \\
\hline CBEC does not Granger Cause $\$$ POV3_1 & 174 & 0.05286 & 0.9485 \\
\hline \$ POV3_1 does not Granger Cause CBEC & & 0.07029 & 0.9322 \\
\hline
\end{tabular}

\section{Conclusion}

Thus, this paper has been devoted to relevant empirical study to clarify the impact of FDI on poverty in the case of the North African country during the period from 1985 to 2005. The sample used in our paper consists of 6 countries of North Africa during the period from 1985 to 2005.

We conduct a descriptive analysis based on the interpretation of descriptive statistics, correlation test and the unit root test. We concluded that on the basis of the test statistics of Im-Pesaran-Shin (IPS) test ADF-Fisher and the test of PP-Fisher, we can conclude that only three variables LIDE, LPIB, LINF and are stationary in LUE level. But first difference, all variables are stationary according to these three tests. Thereafter, all the variables are integrated of order 1 . Thus, we can use the cointegration test. We interpreted the results of cointegration test, model error correction, the estimated FMOLS model and Granger causality test.

For the co-integration test, we have certified the existence of a cointegration relationship between the different series studied in our paper. Indeed, the results of the null hypothesis test of no cointegration were rejected at the $5 \%$ threshold, which explains the presence of a cointegration relationship. The results of these tests can determine the use of an error correction model. Also, to test the effect of FDI on poverty in the countries of North Africa, we will perform a FMOLS estimate. 
Thus, for the short-term dynamics, we noticed that FDI have a positive and significant impact on a threshold of $1 \%$ on the GINI index for the case of the countries of North Africa and a significant negative a threshold of $1 \%$ for the other two indicators of poverty; LPOV1_91 \$ and LPOV3_1 \$.

Then we found that the LIDE variable measuring foreign direct investment has a negative impact on the Gini index to a threshold of 5\%. That is to say, if the level of FDI increased by 5 units, then the GINI index decreases by 0.007476 units.

Finally, Granger causality test, we noticed that there is a unidirectional relationship between the consumption of energy and poverty Granger. Only the GINI index can cause Granger consumption of energy.

\section{References}

Bharadwaj, A. (2014). Reviving the globalisation and poverty debate: Effects of real and financial integration on the developing world. Advances in Economics and Business, 2(1).

Calvo, C. C., \& Hernandez, M. A. (2006). Foreign direct investment and poverty in Latin America, Leverhulme Centre for Research on Globalisation and Economic Policy, University of Nottingham.

Fowowe, B., \& Shuaibu, M. I. (2014). Is foreign direct investment good for the poor? New evidence from African Countries. Eco Change Restruct, 47. https://doi.org/10.1007/s10644-014-9152-4

Gorg, H., \& Greenaway, D. (2004), Much ado about nothing? Do domestic firms really benefit from foreign direct investment? The World Bank Research Observer, 19(2). https://doi.org/10.1093/wbro/lkh019

Hung, T. T. (1999). Impact of Foreign Direct Investment on Poverty Reduction in Vietnam, IDS Program, GRIPS.

Im, H., \& McLaren, J. (2015). Does Foreign Direct Investment Raise Income Inequality in Developing Countries? A New Instrumental Variables Approach. Retrieved from https://www.rse.anu.edu.au/media/772451/ImHyejoon.pdf

Jalilian, H., \& Weiss, J. (2002). Foreign direct investment and poverty in the ASEAN region. ASEAN Economic Bulletin, 19(3). https://doi.org/10.1355/AE19-3A

Mahmood, H., \& Chaudhary, A. R. (2012). A contribution of foreign direct investment in poverty reduction in Pakistan. Middle East Journal of Scientific Research, 12(2).

Meyer, K. E. (2004). Perspectives on Multinational enterprises in emerging economies. Journal of International Business Studies, 35(4). https://doi.org/10.1057/palgrave.jibs.8400084

Reiter, S. L., \& Steensma, H. K. (2010). Human development and foreign direct investment in developing countries: the influence of foreign direct investment policy and corruption. World Development, 38(12). https://doi.org/10.1016/j.worlddev.2010.04.005

Shamim, A., Azeem, P., \& Naqvi, M. A. (2014). Impact of foreign direct investment on poverty reduction in Pakistan. International Journal of Academic Research in Business and Social Sciences, 4(10). https://doi.org/10.6007/IJARBSS/v4-i10/1244

Sumner, A. (2005). Is foreign direct investment good for the poor? A review and stocktake. Development in Practice, 15(3/4). https://doi.org/10.1080/09614520500076183

Ucal, M. S. (2014). Panel data analysis of foreign direct investment and poverty from the perspective of developing countries. Social and Behavioral Science, 109. https://doi.org/10.1016/j.sbspro.2013.12.594

Uttama, N. P. (2015). Foreign Direct Investment and Poverty Reduction Nexus in South East Asia, [in:] Silber J. Poverty Reduction Policies and Practices in Developing Asia.

Zaman, K., Khan, M. M., \& Ahmad, M. (2012). The relationship between foreign direct investment and pro-poor growth policies in Pakistan: The new interface. Economic Modelling, 29. https://doi.org/10.1016/j.econmod.2012.04.020

\section{Copyrights}

Copyright for this article is retained by the author(s), with first publication rights granted to the journal.

This is an open-access article distributed under the terms and conditions of the Creative Commons Attribution license (http://creativecommons.org/licenses/by/4.0/). 